\title{
Analysis of idiotypes expressed by anti-mycobacterial mouse monoclonal antibodies using rabbit antisera
}

\author{
J IVANYI \& K PRAPUTPITTAYA \\ MRC Tuberculosis and Related Infections Unit, \\ Hammersmith Hospital, Ducane Road, London W 12, England
}

\begin{abstract}
Rabbit antisera against twelve mouse monoclonal antibodies to mycobacterial antigens showed idiotype-specificity following cross-absorption with normal mouse globulin. The functional aspects have been partly evaluated so far with two of these reagents. The representation of ML04 idiotype appeared to be associated with Igh alleles. Injection of mice with Rb04 anti-Id in incomplete Freunds adjuvant induced $\mathrm{Id}^{+}$serum levels but without corresponding antigen binding specificity. In contrast, Rb71 anti-Id revealed internal image properties corresponding to the homologous $38 \mathrm{kd}$ protein antigen of tubercle bacilli. This was demonstrated by the potency of Rb71 to sensitize mice in vivo and to elicit $\mathrm{T}$ cell proliferative and DTH responses.
\end{abstract}

\section{Introduction}

It is generally believed that leprosy and tuberculosis occur only in a minority of infected subjects. Therefore, the development of disease may possibly be due to a defect in the host immune system. While the mechanisms are not fully understood, it is likely that the defect is antigen specific since most patients are not generally immunocompromised. Interest has focused on the $\mathrm{T}$ cell-macrophage inter-relationship since these cells were shown to be responsible for protection in mouse models of infection with tubercle bacilli and $M$. leprae $(1,2)$.

Antibody levels are increased in lepromatous leprosy (3-5), as well as in pulmonary tuberculosis $(6,7)$, but except a few studies $(8,9)$, they have so far not been considered to play a role in the pathogenesis of these diseases. We initiated the study of idiotypes expressed on anti-mycobacterial antibodies with the view to bridge over this gap in our knowledge. Our approach seemed justified by experimental studies which demonstrated that various manipulations of the B cell immune system can profoundly perturb T-cell mediated immune reactions (10-12). In this context, it is also intriguing that the extent of chronic granulomatous reactions to BCG in mice (with associated $\mathrm{T}$ cell anergy) has been linked with the Igh locus which controls the structure of immunoglobulin (Ig) heavy chains (13).

It was reported in previous studies that polyclonal antisera raised against Ig idiotypes, can induce in vivo DTH reactions, or T-helper mediated responses with specificity relating to the original antigen (14-18). The broad aims of this study were therefore to explore, in similar experimental models, the biological potency of anti-idiotypic reagents directed towards the monoclonal antibodies (MABs) to mycobacterial antigens. This paper describes the pre- 
liminary results from experiments which will be fully reported elswhere (Praputpittaya and Ivanyi, in preparation).

\section{Production of rabbit anti-idiotype antisera}

Globulin fractions precipitated by $16 \% \mathrm{Na}_{2} \mathrm{SO}_{4}$ from the ascitic fluid of twelve hybridoma MABs (19-23) were injected to New Zealand White rabbits in incomplete Freunds adjuvant (IFA). Antisera were extensively absorbed by affinity chromatography on normal mouse Ig (NMIg) coupled CNBr-Sepharose 4B columns. The idiotype restricted specificity of absorbed sera was established by their binding to polyvinyl 96 well plates coated with the homologous MAB-Ig, and the lack of binding to NMIg or heterologous MAB-Ig coated plates. Furthermore, the anti-Id sera were tested by two immunoassays schematically described in Table 1 .

Table 1. Competition immunoassays employed for the characterisation of anti-Id antibodies.

\begin{tabular}{lll} 
Stage of the test & $\begin{array}{l}\text { Paratope } \\
\text { (SACT) }\end{array}$ & $\begin{array}{l}\text { Assiotype } \\
\text { (AICT) }\end{array}$ \\
\hline
\end{tabular}

\begin{tabular}{lll}
\hline $\begin{array}{l}\text { Coating of polyvinyl } 96 \text { well } \\
\text { plates: }\end{array}$ & $\begin{array}{l}\text { Mycobacterial } \\
\text { soluble extract }\end{array}$ & $\begin{array}{c}\text { Rabbit anti-Id } \\
\text { serum or Ig }\end{array}$
\end{tabular}

(MLSE, MTSE)

Serial dilution of: test sera(antibodies)

125I-labelled reagent $\quad \mathrm{Id}^{+}-\mathrm{MAB}-\mathrm{Ig}\left(\mathrm{Na}_{2} \mathrm{SO}_{4} \mathrm{ppt}\right)$

SACT $=$ serum antibody competition test

AICT $=$ anti-idiotype competition test

MLSE = Mycobacterium leprae soluble extract

MTSE = Mycobacterium tuberculosis soluble extract

Antibody levels are expressed as reciprocal serum dilutions (titres) giving $50 \%$ inhibition of binding $\left(\mathrm{ID}_{50}\right)$.

The inhibitory activity of anti-Ids in the SACT assay localised the Ids within the antibody combining site whereas the AICT assay determined the binding specificity when comparing pairs of MAB-anti-Ids. The basic characteristics of tested MABs are summarised in Table 2. All anti-Ids blocked the MAB-antigen binding and their potency is expressed by titre in the SACT assay. The idiotypes of two groups of four MABs each of overlapping paratope specificity towards the $12 \mathrm{kd}$ and $35 \mathrm{kd}$ M.leprae specific epitopes respectively were analysed by the AICT and SACT assays. One Id shared between three MABs and another distinct Id were identified in both groups (Table 2). The structural localisation of Ids was examined by the immunoblot analysis of separated H\&L chains from reduced/alkylated MAB-Ig following SDS-polyacrylamide gel electrophoresis. The results showed the binding of $\mathrm{Rb} 06$ to $\mathrm{H}$ chains and Rb78 to L-chains, whereas all other anti-Ids reacted only to intact Ig molecules.

\section{Expression of Ids in genetically defined mouse strains}

In initial studies, the occurrence of Ids in the antibody repertoire of MLSE-immunized mice 
Table 2 Review of anti-idiotype antibodies

\begin{tabular}{|c|c|c|c|c|c|c|c|}
\hline $\begin{array}{l}\text { Code of } \\
\text { rabbit } \\
\text { anti-Id }\end{array}$ & MAB(Ig) & Antigen $^{3}$ ) & M.lep. & $\begin{array}{l}\text { pecificty o } \\
\text { M.tuber. }\end{array}$ & $\begin{array}{l}\text { MAB } \\
\text { Others. }\end{array}$ & $\begin{array}{l}\text { Idiotype } \\
\text { expression }\end{array}$ & $\begin{array}{c}\text { Anti-Id } \\
\text { SACT } \\
\text { titre }\end{array}$ \\
\hline Rb06 & $\operatorname{ML06}(\mathrm{Gl})$ & $12 \mathrm{kd}$ & + & - & - & H-chain & 8000 \\
\hline Rblo & $\left.\operatorname{ML10}(G 2 a)^{1}\right)$ & $12 \mathrm{Kd}$ & + & - & - & Ig & 5000 \\
\hline $\mathrm{Rb} 04$ & $\left.\operatorname{MLO4}(\mathrm{Gl})^{2}\right)$ & $35 \mathrm{kd}$ & + & - & - & $\mathrm{Ig}$ & 10000 \\
\hline Rb38 & ML38 (G1) & & & - & & Ig & 3500 \\
\hline Rb30 & $-\operatorname{ML30}(\mathrm{G} 1)$ & $65 \mathrm{kd}$ & + & + & broad & $\mathrm{Ig}$ & 20000 \\
\hline Rb34 & ML34 (M) & $25-40 \mathrm{kd}$ & + & + & broad & Ig & 3500 \\
\hline $\mathrm{Rb} 02$ & ML02 (G3) & $2 J-40 \mathrm{Ka}$ & + & + & Diodu & Ig & 600 \\
\hline $\mathrm{Rb} 23$ & TB23(G1) & $19 \mathrm{kd}$ & - & + & limited & Ig & 700 \\
\hline $\mathrm{Rb} 78$ & TB78 (G1) & $65 \mathrm{kd}$ & - & + & limited & L-chain & 2700 \\
\hline Rb68 & TB68 (G1) & $14 \mathrm{kd}$ & - & + & M.bovis & Ig & 100 \\
\hline $\mathrm{Rb} 71$ & TB71 (G2b) & $38 \mathrm{kd}$ & - & $t$ & - & $\mathrm{Ig}$ & 700 \\
\hline Rb72 & TB72 (G1) & & - & + & & Ig & 500 \\
\hline
\end{tabular}

1) overlapping idotype on ML05 (G2a) and ML12 (G2b)

2) overlapping idotype on ML03 (G1) and ML11 (G1)

3) All antigens are proteins except the 25-40kd lipoarabinomannan-B (24).

was determined. In view of the genetic control of immune responses to mycobacterial antigens by $\mathrm{H}-2$ and non-H-2 genes (25-28), it was of interest to examine the genetic association of Ids in various inbred strains. Mice congenic for alleles controlled by Igh or H-2 loci were immunized with the soluble extract from M.leprae (MLSE) and serum anti-35kd antibodies were examined quantitatively (Table 3). The results indicated that ML04-paratope antibody titres followed a hierarchy which was linked with the Igh locus, but unrelated to the H-2 haplotype. The $\mathrm{Rb} 04$-idiotype also followed a similar pattern but quantitatively less pronounced. However, this genetic association was not apparent in the overall antibody binding potency tested with MLSE-coated plates.

Table 3 Genetic control of the $35 k d$ (ML04) antibody response

\begin{tabular}{lccccc}
\hline Strain & H-2 & Ig-h & $\begin{array}{c}\text { Paratope } \\
\mathrm{ID}_{50} \times 10^{-3}\end{array}$ & $\begin{array}{c}\text { Idiotype } \\
\% \text { Binding } \\
\text { 1/20 Serum dil. }\end{array}$ & $\begin{array}{c}\text { MLSE } \\
\% \text { Binding } \\
\text { 1/500 dil. }\end{array}$ \\
\hline BALB.B & $\mathrm{b}$ & $\mathrm{a}$ & 2.95 & 28.5 & 24.4 \\
BALB.K & $\mathrm{k}$ & $\mathrm{a}$ & 1.79 & 42.3 & 10.7 \\
BALB.C & $\mathrm{d}$ & $\mathrm{a}$ & 1.01 & 32.5 & 62.0 \\
CBA.AK & $\mathrm{k}$ & $\mathrm{d}$ & 1.28 & 32.9 & 13.7 \\
CBA.Ca & $\mathrm{k}$ & $\mathrm{j}$ & .89 & 44.2 & 24.4 \\
CBA.101 & $\mathrm{k}$ & $\mathrm{b}$ & .51 & 17.7 & 7.6 \\
B10.D2/N & $\mathrm{d}$ & $\mathrm{b}$ & .30 & 19.1 & 44.5 \\
CB20 & $\mathrm{d}$ & $\mathrm{b}$ & .26 & 12.4 & 50.0 \\
\hline
\end{tabular}


It is of interest that patients with lepromatous leprosy have high levels of antibodies with specificities restricted only to some of the several antigenic constituents of M.leprae (29). Since the ML04 paratope is represented at high titre in these individuals (5), further study of genetic control of this specificity in mice may help to elucidate the mechanisms which determine it's immunodominance.

\section{The nature of Id $+(« \mathrm{Ab3} »)$ response in mice injected with rabbit anti-Id serum}

Previous studies had shown that injection of anti-Id antibodies into animals can induce the production of serologically detectable $\mathrm{Id}^{+}$molecules (14,30-32). In these experiments, a certain proportion of $\mathrm{Id}^{+} \mathrm{Ig}$ was shown to bind with homologous antigen, whilst significant amounts of the Id can be expressed on antibodies of combining site specificity directed to other underfined antigens. Whilst the mechanisms regulating the relative representation of Ids in a heterogeneous immune repertoire are poorly understood, they are of fundamental importance for the selection of those anti-Ids which carry the «internal image» and could serve as «surrogate» antigens.

The rabbit anti-Id serum Rb04 was injected $(50 \mu l)$ combined with IFA to BALB/c mice. Subsequently, mice were challenged with MLSE $(50 \mu \mathrm{g})$ initially with and later without IFA (Table 4). Sera harvested at various intervals were titrated in competition assays to determine the $\mathrm{Id}^{+}$and paratope ${ }^{+}$molecules. The results showed significant $\mathrm{Id}^{+}$but no paratope activity in mice injected with Rb04/IFA alone. Paratope titres were demonstrable only in MLSE/IFA immunized mice but without a significant difference between the Rb04 and NRIg (control) primed groups. Moreover Rb04/IFA failed to sensitize for challenge with soluble MLSE.

Table 4. Induction of «Ab3» response by injection of BALB/c mice with RbO4 anti-Id.

\begin{tabular}{ccccc}
\hline & Injections (ip): & & \multicolumn{2}{c}{ Serum ID $_{50}$ titre } \\
Rb04-IFA & MLSE-IFA & MLSE-sol. & ML04-Id & ML04-Paratope \\
\hline+ & + & - & 100 & 250 \\
- & + & - & $<10$ & 80 \\
+ & + & + & 200 & 1000 \\
- & + & + & $<10$ & 400 \\
$+(2 \mathrm{x})$ & - & - & 100 & $<10$ \\
$+(2 \mathrm{x})$ & - & + & 200 & $<10$ \\
- & - & - & $<10$ & $<10$ \\
\hline
\end{tabular}

The specificity of antibodies in the sera from double immunized mice was further examined by cross-absorption on either MLSE or Rb04 CNBr-Sepharose 4B column (Table 5). The results clearly showed the presence of two independent populations of molecules with either idiotype or paratope (antigen binding) specificities. Taken together, these experiments suggested that the pronounced $\mathrm{Id}^{+}$response to Rb04/IFA was completely devoid of any binding specificity with the MLSE-derived 35kd antigen.

The following experiment was set up to investigate whether the $\mathrm{Id}^{+}$response to Rb04/IFA could be regulated by mechanisms which operate in murine responses to protein antigens; namely, that the response to antigen-adjuvant injection can be abrogated by prior injection of soluble antigen $(33,34)$. Soluble Rb04 $(2 \times 50 \mu 1)$ was given prior to challenge of mice with Rb04/IFA (Table 6). This protocol resulted in significant suppression of the $\mathrm{Id}^{+}$serum values 
Table 5. Dissociation betwen Rb04-Id ${ }^{+}$and $35 \mathrm{kd}$ antigen specific antibodies

\begin{tabular}{lcc}
\hline Serum from & \multicolumn{2}{c}{ ID $_{50}$ serum titre } \\
Rb04 (anti-Id) plus MLSE(Ag) & Paratope & Idiotope \\
injected mice & 1070 & 270 \\
\hline Untreated & $<10$ & 260 \\
Absorbed: MLSE CNBr-Sepharose 4B & 895 & $<10$ \\
Absorbed: Rb04 CNBr-Sepharose 4B & & \\
\hline
\end{tabular}

Table 6. Modulation of the "Ab3» response induced by Rb04 anti-Id.

\begin{tabular}{|c|c|c|c|c|c|c|c|}
\hline \multirow[b]{2}{*}{ Group } & \multirow{2}{*}{$\begin{array}{c}\mathrm{CY} \\
50 \mathrm{mg} / \mathrm{kg} \\
-23 \mathrm{~d}\end{array}$} & \multirow{2}{*}{$\begin{array}{c}\text { Rb04 } \\
\text { sol. } \\
-21,-14 d\end{array}$} & \multirow{2}{*}{$\begin{array}{c}\text { Rb04 } \\
\text { /IFA } \\
\text { od }\end{array}$} & \multicolumn{4}{|c|}{ Antibody level $(+10 \mathrm{~d})+$ SE* $)$} \\
\hline & & & & $\begin{array}{l}\% \text { Inhibition } \\
\text { in AICT }\end{array}$ & & $\begin{array}{l}\% \text { Binding } \\
\text { to NRIg }\end{array}$ & \\
\hline 1 & - & - & - & $37.5 \pm 0.6$ & & $26.0 \pm 0.8$ & \\
\hline 2 & - & - & + & $62.8 \pm 2.3$ & & $53.1 \pm 2.8$ & NS \\
\hline 3 & - & + & + & $31.5 \pm 2.1\}$ & $\mathrm{p}<.001$ & $52.1 \pm 1.7$ & NS \\
\hline 4 & + & + & + & $66.4 \pm 5.8$ & & $59.2 \pm 1.7$ & \\
\hline
\end{tabular}

*) at $1 / 20$ serum dilution.

(group 3). In accordance with the response to protein antigens (35) the suppressive effect of Rb04 without IFA was abrogated by prior injction of cyclophosphamide (group 4, Table 6). Injection of Rb04/IFA also induced antibodies binding to normal rabbit Ig; however this response was not suppressed by prior injection of Rb04 alone. The CY-sensitive mechanism which implies the role of $\mathrm{T}$ suppressor cells (36) may play a regulatory role in response to the anti-Id-specific structure of the rabbit antibody.

«Internal image» activity of $\mathrm{Rb} 71$ anti-Id for $\mathrm{T}$ cell proliferative and DTH reactions Experiments on the modulation of human $\mathrm{T}$ cell proliferative responses to the soluble extract from M.tuberculosis (MTSE) revealed that Rb71 anti-Id stimulated the in vitro ${ }^{3} \mathrm{H}$-TdR uptake by peripheral blood mononuclear cells from BCG-vaccinated donors (37). Stimulation by $\mathrm{Rb} 71$ anti-Id associated with responsiveness to the corresponding $38 \mathrm{kd}$ protein antigen. Furthermore, T cell clones were established which proliferated to either Rb71 or 38kd antigen only in the presence of irradiated autologous antigen presenting cells. Subsequent experiments in mice aimed to confirm and expand the analysis of the «surrogate» antigen characteristics of Rb71 anti-Id.

Mice were sensitized by subcutaneous injection of $50 \mu \mathrm{g}$ MTSE/IFA or Rb71/IFA and spleen cells were harvested for in vitro study using standard microwell culture techniques. Stimulation of ${ }^{3} \mathrm{H}-\mathrm{TdR}$ uptake by spleen cells from MTSE/IFA immunized mice was achieved by $\mathrm{Rb} 71$ but not by $\mathrm{Rb} 72, \mathrm{Rb} 78, \mathrm{Rb} 23, \mathrm{Rb} 68$, and $\mathrm{Rb} 34$. The proliferative response to Rb71 (affinity purified on a column of TB71-Ig coupled to CNBr-Sepharose) was abrogated by prior treatment of spleen cells with anti-Lyt 1.2 serum and complement (Table 7). These results suggest that the responding cells belong to the $\mathrm{T}$ helper/inducer subset. In a separate 
experiment, spleen cells taken from Rb71/IFA injected mice showed a significant proliferative response to the purified $38 \mathrm{kd}$ protein. Thus, Rb71 anti-Id had imparted the $38 \mathrm{kd}$ antigen activity as the immunogen in vivo as the well as the inducer of $\mathrm{T}$ cell proliferation in vitro.

Table 7. Stimulation of splenic T cells from MTSE-sensitized mice with affinity purified Rb7 I anti-Id.

\begin{tabular}{lccccccr}
\hline & & \multicolumn{5}{c}{${ }^{3} \mathrm{H}-\mathrm{TdR}, \times 10^{-3} \mathrm{cpm} ; 7$ day culture } \\
\cline { 3 - 8 } Exp & Priming & $\begin{array}{c}\text { Cell } \\
\text { Treatment } \\
\text { plus C' }\end{array}$ & - & NRIg & Rb7l & $38 \mathrm{kd}$ & MTSE \\
& & & & & & \\
\hline 1 & MTSE & - & 0.93 & 0.86 & 21.53 & NT & 51.65 \\
& MTSE & a-Lyt 1.2 & 1.59 & 0.72 & 2.46 & NT & 3.05 \\
\hline 2 & MTSE & - & 3.66 & 0.86 & 10.96 & 15.75 & 11.10 \\
& Rb71 & - & 3.55 & 13.20 & 15.43 & 18.32 & 5.66 \\
\hline
\end{tabular}

Table 8. Antigen surrogate activity of Rb71 anti-Id for DTH responses of BALB/C mice

\begin{tabular}{|c|c|c|c|}
\hline \multirow{2}{*}{$\begin{array}{c}\text { Sensitisation } \\
\text { with soluble extract or } \\
\text { rabbit Ig }\end{array}$} & \multicolumn{3}{|c|}{ Footpad swelling ( $\mathrm{mm} \times 10^{-2} \pm \mathrm{SE}$ ) elicited by: } \\
\hline & MTSE & $\mathrm{Rb} 71$ & NRG \\
\hline M.tuberculosis & $77 \pm 6 *$ & $51 \pm 3^{*}$ & $17 \pm 2$ \\
\hline M.bovis & $93 \pm 6 *(1)$ & $72 \pm 5^{*}$ & $7 \pm 2$ \\
\hline M.leprae & $55 \pm 2 *(1)$ & $23 \pm 4$ & $17 \pm 2$ \\
\hline Rb71 anti Id & $47 \pm 3 *$ & NT & NT \\
\hline NRG & $18 \pm 8$ & NT & NT \\
\hline
\end{tabular}

$* \mathrm{p}<0.01$ when compared with NRG (normal rabbit Ig).

(1) Elicitation with soluble extract homologous with the sensitising species of mycobacterium

Mice were sensitised for delayed type hypersensitivity (DTH) by subcutaneous injection of mycobacterial antigens $(50 \mu \mathrm{g})$ or anti-Id $(5 \mu \mathrm{g})$ emulsified in IFA, two days after pretreatment with $50 \mathrm{mg} / \mathrm{kg}$ cyclophosphamide (the latter is known to amplify mouse DTH reactions). The eliciting footpad injections of $10 \mu \mathrm{g}$ MTSE or $5 \mu \mathrm{g}$ rabbit Ig were given two weeks after priming and footpad swelling reactions were measured after 24 hours (Table 8). Rb71 elicited significant DTH reactions in mice sensitised with soluble extracts from M.tuberculosis or M.bovis, but not with M.leprae. Although MAB-TB71 reacts only weakly ( $10 \%$ when compared with M.tuberculosis) with M.bovis, there is an apparently pronounced cross-reactivity in the recognition of the $38 \mathrm{kd}$ antigen by $\mathrm{T}$ cells. This result is in accord with the observed proliferative response of lymphocytes from BCG vaccinated human subjects to the $38 \mathrm{kd}$ protein (22). In the reverse combination, sensitisation with $\mathrm{Rb} 71$ resulted in a significant DTH response elicited by MTSE (containing the $38 \mathrm{kd}$ antigen) whilst normal rabbit Ig failed to sensitise. 


\section{Concluding comments}

Results have been presented which demonstrate the contrasting behaviour of two anti-idiotypic antibodies. Rb04 effectively stimulated an $\mathrm{Id}^{+}$serum Ig response, but without internal image of the corresponding $35 \mathrm{kd}$ protein antigen of $M$.leprae. On the other hand, antibody Rb71 could sensitize and elicit T-cell mediated proliferative and DTH reactions specific for the homologous $38 \mathrm{kd}$ protein antigen. The interpretation of these findings should be considered on the basis of mechanisms which determine the immunodominance of B cell or $\mathrm{T}$ cell stimulatory epitopes of protein antigens. It is generally believed that «hapten» and «carrier» like paired structures are mutually exclusive. this is expected to be the outcome of the distinct recognition mechanisms operated by B and T cells respectively. Consequently, idiotypic domains within the combining site of the majority of antibodies would not be shared with the $\mathrm{T}$ cell receptor. However, it is conceivable that in certain instances antibodies can be directed towards the same epitope which is presented in association with MHC Class II molecules on the surface of accessory cells to T cells. In this case the antibody combining site and the $\mathrm{T}$ cell receptor may contain a common idiotype which is complementary for the same epitope of the antigen. This hypothesis needs verification by further structural and functional analysis of the Rb71 idiotype. Moreover, the proposed interpretation when tested experimentally, may provide a rationale for a more predictable selection of such anti-idiotypic antibodies which carry the internal image of $\mathrm{T}$ cell epitopes.

\section{References}

1 Mackaness GB. the immunology of anti-tuberculous immunity. American Review of Respiratory Diseases. 1968; 97:337-344.

2 Rees RJW, Waters MFR, Wedell AGM \& Palmer E. Experimental lepromatous leprosy. Nature 1966; 215: 599-602.

3 harboe M, Closs O, Bjune G, Kronvall G and Axelsen NH. Mycobacterium leprae specific antibodies detected by radioimmunoassay. Scand. J. Immunol. 1978; 7:111-120.

4 Melsom R. Serodiagnosis of Leprosy: The past, the present, and some prospects for the future. Int. J. Lepr. 1983; 51(2):235-252.

5 Sinha S, Sengupta U, Ramu G \& Ivanyi J. A serological test for leprosy based on competitive inhibition of monoclonal antibody binding to the MY2a determinant of Mycobacterium leprae. Trans. R. Soc. Trop. Med. Hyg. 1983; 77:869-871.

6 Grange JM. the humoral immune resonse in tuberculosis: its nature, biological role and diagnostic usefulness. Advances in Tubercle Research 1984; 21:1-78.

7 Hoeppner VH, Jackett PS, Beck JS, Karjito T, Grange JM, Ivanyi J. Appraisal of the monoclonal antibody-based competition test for the serology of tuberculosis in Indonesia. Serodiagnosis and Immunotherapy. Accepted for publication.

8 Forget A, Benoit JC, Turcotte R, and Gusew-Chartrand N. Enhancement activity of antimycobacterial sera in experimental Mycobacterium bovis (BCG) infection in mice. Infect. Immunity. 1976; 13:1301-1306.

9 Gros P and Forget A, Modulating effect of passive immunization with anti-Mycobacterium tuberculosis antibodies on humoral response in BCG-infected mice. Int. Arch. Allergy Appl. Immunol. 1980; 63(4):446-454.

10 Bottomly K, Janeway CA, Matieson BJ, and Mosier DE. Absence of an antigen-specific helper $\mathrm{T}$ cell required for the expression of the T 15 idiotype in mice treated with anti- $\mu$ antibody. Eur. J. Immunol. 1980; 10:159-163.

11 Kim KJ, Rollwagen F, Asofsky R and Lefkovits I. The abnormal function of $\mathrm{T}$ cells in chronically anti- $\mu$-treated mice with no mature B lymphocytes. Eur. J. Immunol. 1984; 14: $476-482$. 
12 Sy MS, Lowy A, Hayglass K, Janeway CA, Gurish M, Greene MI and Benacerraf B. Chronic treatment with rabbit anti-mouse $\mu$-chain antibody alters the characteristic immunoglobulin heavy-chain restriction of murine suppressor T-cell factors. proc. natl. Acad. Sci. USA. 1984; 81:3846-3850.

13 Schrier DJ, Sternick JL, Allen EM \& Moor VL. Immunogenetics of BCG-induced anergy in mice: control by genes linked to the Igh complex. J. Immunol. 1983; 128: 1466-1469.

14 Eichmann K. Expression and function of idiotypes on lymphoctes. Adv. Immunol. 1978; 26:195-254.

Julius $\mathrm{MH}$, Consenza $\mathrm{H}$ and Augustin AA. Evidence for the endogenous production of $\mathrm{T}$ cell receptors bearing idiotypic determinants. Eur. J. Immunol. 1978; 8:484-491.

16 Yamamoto HM, Nonaka M and Katz DH. Suppression of hapten-specific delayed type hypersensitivity responses in mice by idiotype-specific suppressor T cells after administration of anti-idiotypic antibodies. J. Exp. Med. 1979; 150:818-829.

17 Sy MS, Brown AR, Benacerraf B and Greene MJ. Antigen and receptor driven regulatory mechanisms. III. Induction of delayed-type hypersensitivity to azobenzenearsonate with anti-cross-reactive idiotype antibodies. J. Exp. Med. 1980; 151:896-909.

18 Thomas WR, Morahan G, Walker JD and Miller JFAP. Induction of delayed type hypersensitivity to azobenzenearsonate by a monoclonal anti-idiotype antibody. J. Exp. Med. 1981; 153:743-747.

19 Coates ARM, Allen BW, Hewitt J, Ivanyi J and Mitchison DA. Antigenic diversity of Mycobacterium tuberculosis and Mycobacterium bovis detected by means of monoclonal antibodies. Lancet 1981; ii: 167-169.

20 Ivanyi J, Sinha S, Aston R, Cussell D, Keen M and Sengupta U. Definition of speciesspecific and cross-reactive antigenic determinants of Mycobacterium leprae using monoclonal antibodies. Clin. exp. Immunol. 1983; 52:528-536.

21 Ivanyi J, Morris JA and Keen M. Studies with monoclonal antibodies to mycobacteria. In Macario AJL \& Macario EC (eds) Monoclonal Antibodies Against Bacteria 1985; pp 59-90. New York: Academic Press.

22 Young DY, Kent L, Rees A, Lamb J, and Ivanyi J. Immunological activity of a 38 kilodalton protein purified from Mycobacterium tuberculosis. Infect. Immunity. 1986; 54.

23 Engers HD, Bloom BR and Godal T. Monoclonal antibodies against mycobacterial antigens. Immunology Today 1985; p346-347.

24 Brennan PJ, Hunter SW, Chatterjee D, cho SN, and Gaylord H. Carbohydrate based Antigens on the Leprosy Bacillus. Indo-US Symposium on Immunology \& Molecular Biology of leprosy 1986; p49.

25 Closs O, Lovik M, Wigzell $\mathrm{H}$ and Taylor BA. H-2-linked gene(s) influence the granulomatous reaction to viable Mycobacterium lepraemurium in the mouse. Scand J. Immunol. 1983; 18:59-63.

26 Douglas-Jones AG and Watson JD, Immunity to leprosy. II. Genetic control of murine T cell proliferative responses to Mycobacterium leprae. J. Immunol. 1985; 135: 2824-2828.

27 Tauscher C, Yanagihara D, Brennan PJ, Koster FT and Tung KSK. Antibody response to phenolic glycolipid I in inbred mice immunized with Mycobacterium leprae. Infect. Immunity. 1985; 48:474-479.

28 Ivanyi J, Sharp K. Control by $\mathrm{H}-2$ genes of murine antibody responses to protein antigens of M.tuberculosis. Immunology. 1986; in press.

29 Chakrabarty A, Maire M, Saha K and Lambert P-H. Identification of components of IC purified from human sera. II. Demonstration of mycobacterial antigens in immune com- 
plexes isolated from sera of lepromatous patients. Clin. exp. Immunol. 1983; 51: 225-231.

30 Reth M, Kelsoe G and Rajewsky K. Idiotypic regulation by isologous monoclonal anti-idiotope antibodies. Nature 1981; 290:257-259.

31 Geraldine G, Miller P, Nadler PI, Hodes RJ and Sachs DH. Modification of T cell antinuclease idiotype expression by in vivo administration of anti-idiotype. J. Exp. Med. 1982; 155:190-200.

32 Auchincloss H, Jeffrey A. Jnr, Bluestone A and Sachs DH. Antiidiotypes against anti-H-2 monoclonal antibodies V. In vivo antiidiotype treatment induces idiotype-specific helper T cells. J. Exp. Med. 1983; 157:1273-1286.

33 Basten A, Miller JFAP and Johnson P. T cell-dependent suppression of an anti-hapten antibody response. Transplant. Rev. 1975; 26:130-169.

34 Nachtigal D, Zan-Bar I and Feldman M. The role of specific suppressor T cells in immune tolerance. Transplant. Rev. 1975; 26:87-105.

35 Gagnon RF and MacLennan ICM. Regulation of secondary antibody responses in rodents. (1) Potentiation of IgG production by cyclophosphamide. Clin. exp. Immunol. 1979; 37:89-97.

36 Dwyer JM, Parker D and Turk JL. Suppression of delayed hypersensitivity to tuberculin by antigenic competition. A positive immunoregulatory mechanism sensitive to cyclophosphamide. Immunology 1981; 42:549-559.

37 Rees ADM, Praputpittaya K, Scoging A, Dobson N, Ivanyi J, Young D and Lamb JR. T cell activation by anti-idiotypic antibody: evidence for the internal image. Immunology, in press. 